\title{
Resenha do livro "Origens e Evolução da Indústria de Máquinas e Equipamentos em São Paulo: 1870-1960" de Michel Deliberali Marson
}

Marson, Michel Deliberali. Origens e evolução da indústria de máquinas e equipamentos em São Paulo: 1870-1960. São Paulo: Annablume, 2017. 210p.

\section{Gustavo Barros ${ }^{1}$}

Em seu "Origens e evolução da indústria de máquinas e equipamentos em São Paulo: 1870-1960”, Michel Deliberali Marson explora em detalhes o período de constituição no país desse setor estratégico da indústria, bem como a sua evolução subsequente. A historiografia econômica brasileira, com frequência, menosprezou esse período no seu tratamento do setor de bens de capital, e do setor de máquinas e equipamentos, em particular, dando maior relevo a eles em suas análises apenas no período pós-Segunda Guerra Mundial. O livro de Marson oferece-nos uma imagem distinta, ressaltando a importância e o dinamismo da indústria de máquinas e equipamentos em São Paulo, bem como a sua capacidade de resposta às transformações econômicas em andamento no país desde o final do século XIX até meados do século XX. A circunstância de que o setor possuía uma parcela relativamente pequena do valor da produção industrial não diminui a relevância dessa análise. Não apenas essa é uma característica típica do setor de máquinas e equipamentos em outras economias, mas também ele tem uma importância crítica no desenvolvimento econômico, e industrial em particular, como o fornecedor de bens que permitem a expansão da capacidade produtiva dos demais setores e como um vetor de difusão do progresso tecnológico. É dessa perspectiva que parte Marson para o seu tratamento das origens e evolução do setor de máquinas e equipamentos em São Paulo ao longo desse período, fazendo uma análise cuidadosa e fundamentada numa ampla base documental primária.

1 Professor - Universidade Federal de Juiz de Fora (UFJF) - Endereço: Campus Universitário, s/n. - Martelos - Juiz de Fora/MG - Brasil - Email: gustavo.barros@ufjf.edu.br ORCiD: https://orcid.org/0000-0001-5854-8579 - Recebido: 26/09/2018. Aceite: 08/10/2018. 
O livro examina, a princípio, o papel da indústria de máquinas e equipamentos em termos gerais. Aqui encontramos uma discussão sobre as especificidades e a importância desse setor no processo de industrialização, tal como ele se desenrolou na Europa e nos Estados Unidos, de forma a nos oferecer uma referência para a análise do caso paulista. Segue-se uma ampla revisão da historiografia econômica sobre a indústria de máquinas e equipamentos no Brasil, e em São Paulo em particular, das suas origens até a década de 1940. Nessa revisão, vemos ainda Marson resgatar as principais questões relativas ao setor que mobilizaram a historiografia e, ao mesmo tempo, contrapor as principais interpretações a seu respeito. É desse balanço que o autor extrai as preocupações centrais do seu próprio trabalho e com relação ao qual mede as suas contribuições.

A evolução da indústria de máquinas e equipamentos em São Paulo é dividida no trabalho em dois subperíodos. O período de 1870 a 1919 - o das "origens" - e o de 1920 a 1940 - o das "transformações". O tratamento das origens do setor é feito a partir das questões abertas deixadas pela historiografia, preocupado especialmente com os nexos econômicos que estiveram na base do surgimento e crescimento do setor, com a origem dos empresários que se dedicaram a ele e com os efeitos da Primeira Guerra Mundial.

Em suas origens, essa indústria foi marcada por pequenas oficinas e fundições surgidas tipicamente das necessidades de reparos de máquinas importadas e vinculadas a uma demanda local, geralmente em um segmento de mercado específico ligado à economia primário-exportadora. De fato, entre o final do século XIX e as primeiras décadas do século XX, as principais empresas do setor de máquinas e equipamentos atendiam à demanda, direta e indireta, gerada pelas atividades de exportação de produtos primários, especialmente café, algodão e açúcar. Maior conveniência na assistência técnica e uma eventual reposição de peças com mais presteza, assim como a necessidade de máquinas especializadas, de produção artesanal sob encomenda, eram fatores que pesavam nesse caráter marcadamente local da indústria nesse período. A origem dos empresários do setor de máquinas e equipamentos teve, como seria de se esperar, paralelos com a da indústria em geral. Mas o livro nos mostra uma importância ainda maior aqui dos imigrantes, no caso, com frequência com algum tipo de formação ou experiência técnica, e menores ligações com o comércio importador. 
O impacto da Primeira Guerra Mundial sobre a indústria de máquinas e equipamentos foi objeto de alguma divergência na historiografia. Aqui Marson, fazendo uso de registros mensais de constituição de empresas na Junta Comercial de São Paulo entre 1911 e 1920, encontrados no Boletim da Diretoria de Indústria e Comércio da Secretaria de Agricultura do estado de São Paulo, converge com os que viram no período da Primeira Guerra um momento desfavorável para a formação de capital no setor. É certo que a contração da importação de máquinas durante o conflito ensejou a criação de várias pequenas empresas, geralmente voltadas para o reparo de máquinas importadas. Contudo, como destacaram outros autores, muitas dessas empresas não sobreviveram ao fim da Guerra. Ainda assim, o autor mapeia um número de empresas surgidas nesse período que vieram a crescer e se desenvolver ao longo das décadas seguintes, para além do caso mais famoso da Villares.

Marson nota ainda que, a partir da Primeira Guerra e, sobretudo, na década de 1920, observamos uma aceleração do processo de diversificação na indústria de máquinas e equipamentos paulista, manifesto num crescimento de empresas voltadas à produção de máquinas para a indústria e numa mudança na participação relativa dos bens produzidos. O setor acompanhava assim a evolução da economia como um todo e da indústria de transformação em particular. Esse movimento de diversificação teve continuidade ao longo da década de 1930, inclusive com a formação de um núcleo produtor de máquinas para vários setores da indústria e a especialização de algumas empresas na produção de máquinas operatrizes. Núcleo este que viria a dar suporte aos estágios mais avançados da industrialização brasileira em décadas posteriores. Contudo, o livro nos mostra que a crise de 1929 e a Grande Depressão afetaram a indústria de máquinas e equipamentos ainda mais profundamente do que o setor industrial como um todo, tendo o valor da produção daquela perdido participação relativa no total da indústria de transformação entre 1928 e 1931. Esse movimento, por outro lado, seria revertido, com uma recuperação mais rápida da indústria de máquinas e equipamentos entre 1932 e 1935.

Por fim, o trabalho é concluído com dois estudos de caso detalhados, estes cobrindo o período até 1960, e tratando de duas firmas representativas de certos traços gerais da evolução histórica do setor: a Dedini e a Romi. De fato, ambas surgiram como pequenas oficinas nas primeiras décadas do século XX, adaptaram-se com as transformações dos mercados em que atuavam e se fortaleceram no setor na década de 1940, tendo even- 
tualmente se tornado líderes da indústria de máquinas e equipamentos no início dos anos 1960.

Tomado como um todo, o livro de Michel Marson oferece-nos uma contribuição substantiva para a histografia do setor de máquinas e equipamentos paulista. Destaca-se o trabalho pelo exame cuidadoso de uma ampla base documental primária no tratamento do tema, bem por uma contínua interlocução com a historiografia. Além disso, o livro nos chama a atenção para as origens dessa indústria já no final do século XIX, e para as suas transformações nas décadas de 1920, 1930 e 1940, colocando em questão, portanto, a periodização mais aceita da industrialização brasileira, que atribui maior relevância à indústria de máquinas e equipamentos, e ao setor de bens de capital em geral, apenas a partir da década de 1950. Sendo assim, "Origens e evolução da indústria de máquinas e equipamentos em São Paulo: 1870-1960" coloca-se como uma referência de relevo aos interessados na história desse setor e, naturalmente, também na da industrialização brasileira em geral.

\section{Referências}

Marson, Michel Deliberali. Origens e evolução da indústria de máquinas e equipamentos em São Paulo: 1870-1960. São Paulo: Annablume, 2017. 210p. 